\title{
Extensional Tectonics, a Slab Window and the arrival of the Gulf of California about 17Ma, while the Coyote Mountains of southern California, USA undergo $90^{\circ}$ clockwise rotation in Sonora, Mexico
}

George Morgan (georgemorgan@cox.net) and JR Morgan

Prior to 5.5(?) Ma, Winker and Kidwell (1996) place the Coyote Mountains (CMs) of southern California, in Sonora, Mexico. In Sonora, the CMs were deformed by Basin and Range Extension and related regional subsidence that started about 25 Ma (Nourse et al., 1994). The Basin and Range Extension was the first of three episodes of extensional tectonics recorded in the CMs (Morgan and Morgan, 2017a). This first episode of extension left the CMs with the normal Ocotillo Canyon Fault and a related graben containing non-marine synextensional sediments (lower part of the Split Mountain Group). Sometime after the first and before the start of the second episode of extensional tectonics, the CMs start to rotate clockwise about $90^{\circ}$. We interpret the rotation as the product of right-lateral faulting (possible transtensional). During the rotation, 17.1 Ma (Morgan et al., 2012) volcanics of Ruisaard's (1979) Alverson Canyon Formation (upper part of Winker and Kidwell's (1996) Split Mountain Group) were deposited in the CMs as a result of the formation of Dickinson's Slab Window (Dickinson, 1997). The formation of the Slab Window also coincides with the start of the second episode of extensional tectonics and continued regional subsidence. The second episode of extension and continuing subsidence facilitates the arrival of the Gulf of California during the deposition of the volcanics of the Alverson Canyon Formation in the CMs (Woodring, 1931; Morgan and Morgan 2015). 
The marine-nonmarine, second episode, syn-extensional sediments of the Viejo Formation (Morgan and Morgan, 2015) of the Imperial Group, represents the Gulf's arrival in the CMs, while the CMs are still in Sonora. The Viejo Formation is represented by several transgressionalregressional sequences, all of which were deposited near sea- level.

A combination of the following: 1) a weak, thin, warn crust; 2) rightlateral faulting (possible transtensional); 3 ) continuing extensional tectonics and subsidence, is inferred from the CMs. From these inferences it is reasonable to expect pull-a-part basins to be a part of the young Gulf.

Morgan, G, J., and Morgan, J. R., 2018b, Extensional Tectonics, a Slab Window and the arrival of the Gulf of California about 17Ma, while the Coyote Mountains of southern California, USA undergo $90^{\circ}$ clockwise rotation in Sonora, Mexico: Geological Society of America Abstracts with Programs. Vol. 50, No. 5, ISSN 0016-7592 doi: 10.1130/abs/2018RM-314078 


\section{Extensional Tectonics, a Slab Window and the arrival of the Gulf of California about $17 \mathrm{Ma}$, while the Coyote Mountains of southern California, USA undergo $90^{\circ}$ clockwise rotation in Sonora, Mexico}

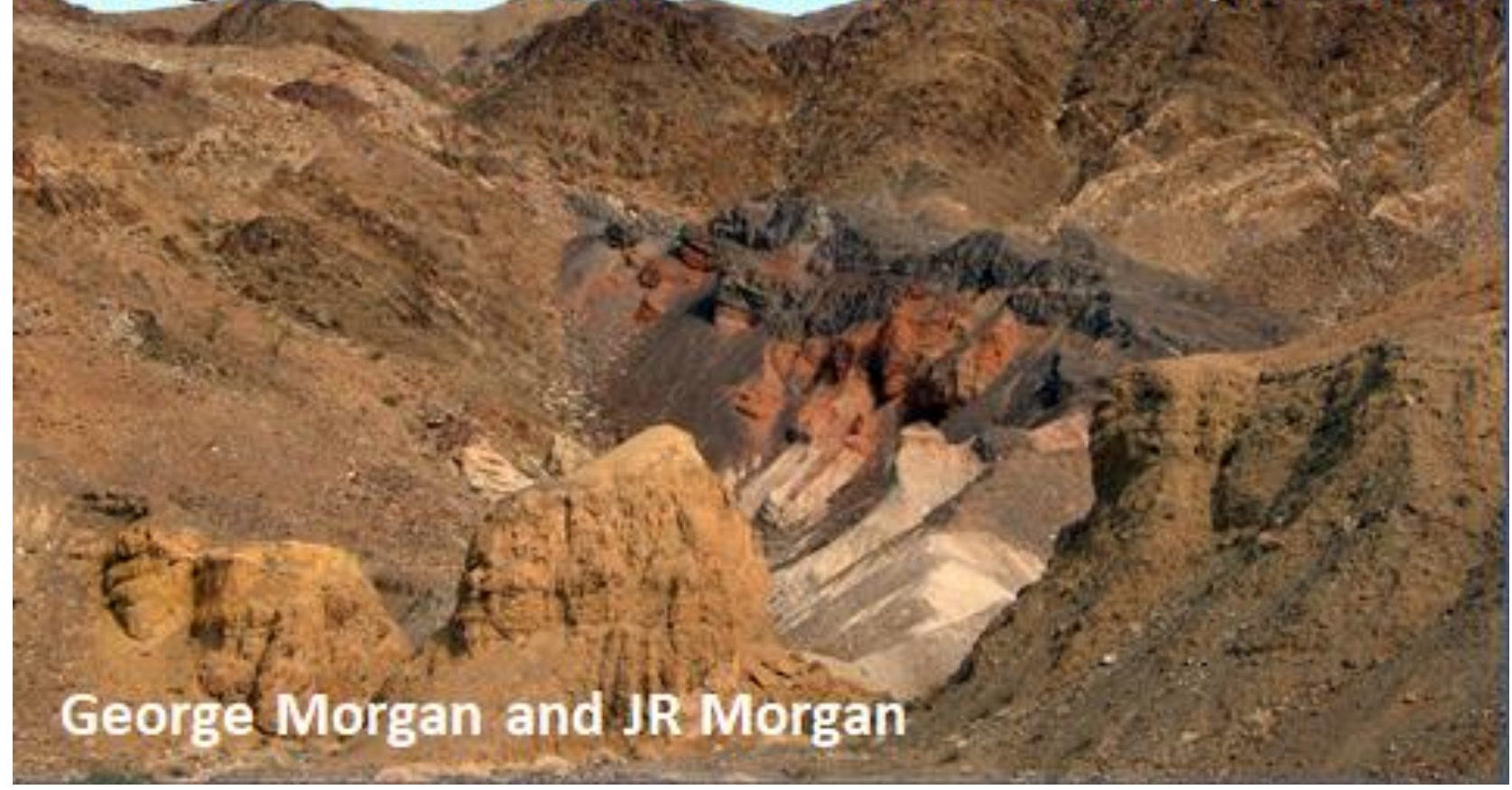

Slide 1. Looking east from the Alverson/Fossil Canyon drainage up a side canyon. White unit is the White Fanglomerate (Morgan and Morgan, 2017a) of the Winker and Kidwell's (1996) Split Mountain Group (SMG). Red Unit is the Red Fanglomerate (Morgan and Morgan, 2017a) of the SMG that interfingers with the volcanics of the Alverson Canyon Formation (Ruisaard, 1979) (black unit) of the SMG. All three units of the SMG form an unconformity with the Jurassic White Cross Gneiss (Morgan and Morgan, 2015) (brown unit) to the left in the photo. The small, light tan butte in the foreground contains a contact between marine and non-marine units of the Viejo Formation (Morgan and Morgan, 2016) of the Imperial Group. This contact is repeated 
along the ridge line, at the end of the word California, in the slide (Morgan and Morgan, 2017a).

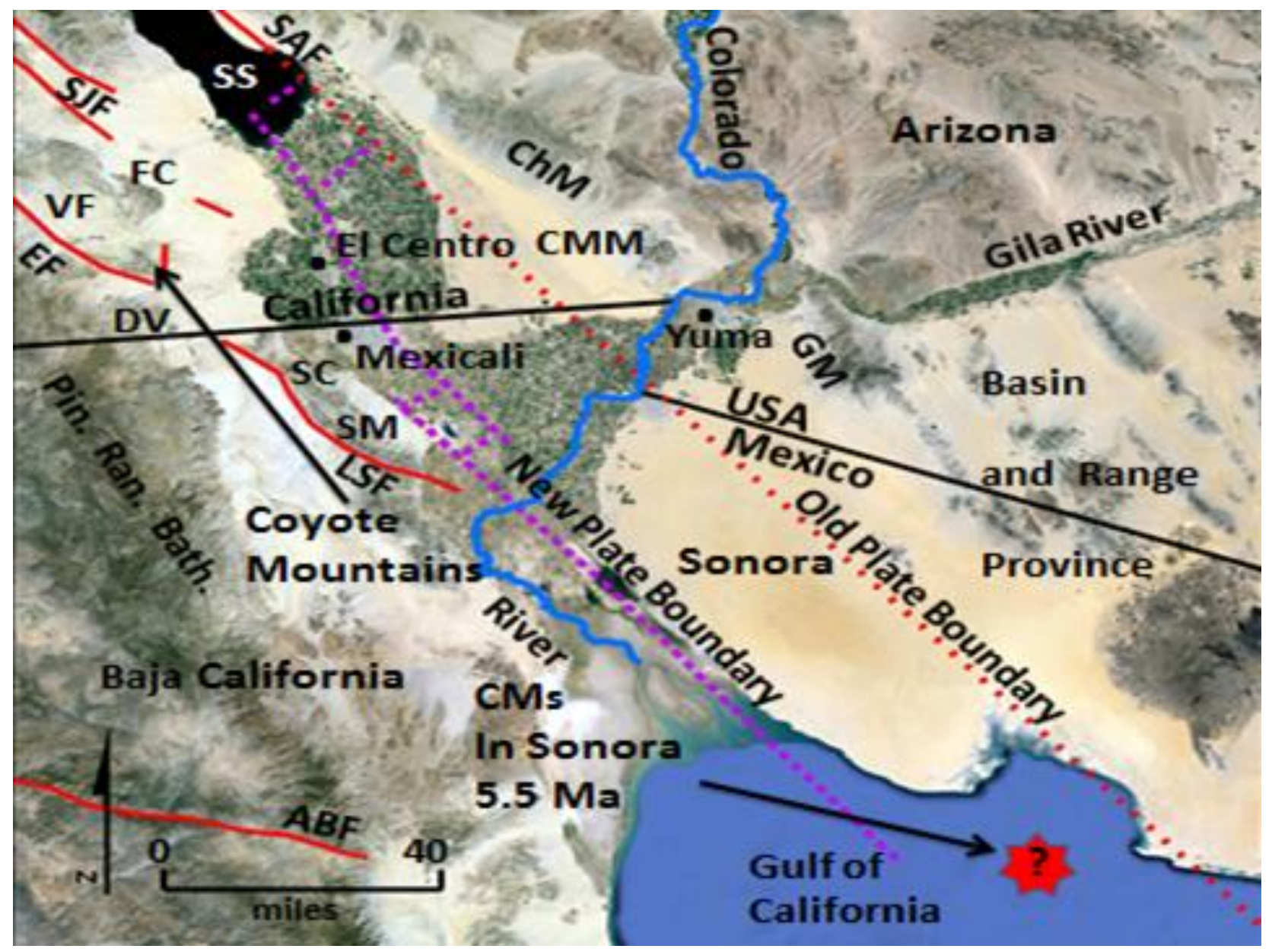

Slide 2. Location Map of the Salton Trough, the CMs in southern California, southwestern Arizona and parts of the States of Baja California and Sonora, Mexico. ABF - Agua Blanca Fault, ChM Chocolate, Mountains, CMM - Cargo Muchacho Mountains, DV Davies Valley, EF - Elsinore Fault, FC - Fish Creek Mountains, GM - Gila Mountains LSF - Laguna Salada Fault, Pin. Ran. Bath. - Peninsular Ranges Batholith, SC - Sierra Cucapa, SM - Sierra El Mayor, SAF - San Andreas Fault, SJF - San Jacinto Fault, SS - Salton Sea, VF - VallicetosSplit Mountain-Fish Creek Basin. Red star with query is the 
paleogeographic location of the CMs at 5.5 Ma by Winker and Kidwell (1996) in Sonora, Mexico. We agree the paleogeographic location for the CMs was somewhere in Sonora, Mexico. Note the orentation of the ranges of the Basin and Range Provance. NASA photograph.

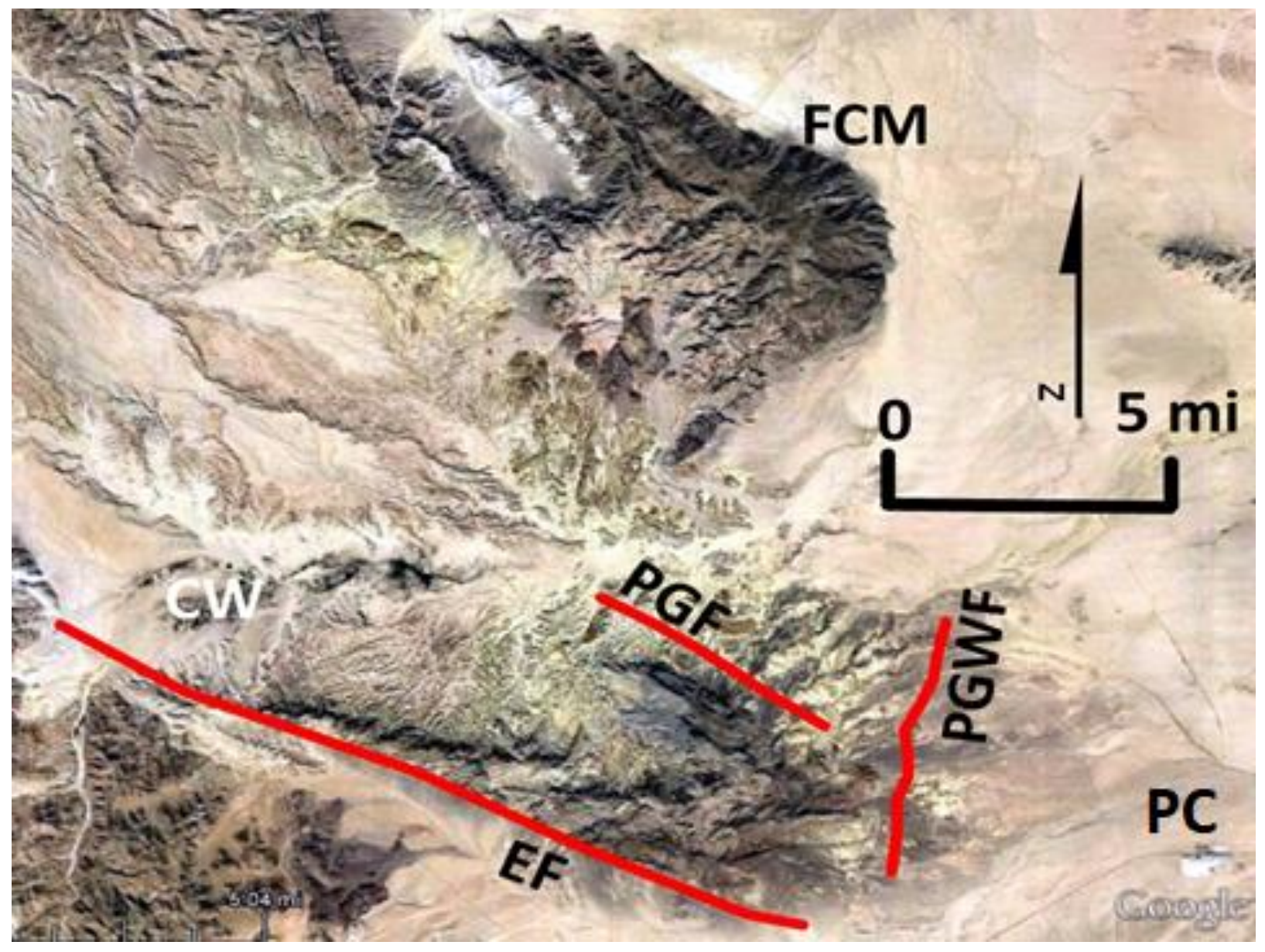

Slide 3. Google Earth Image of the area around the fish-hook shaped CMs. CW-Carrizo Wash flowing east into the Salton Sea. EF- Elsinore 
Fault, an active right lateral fault. FM- Fish Creek Mountains. PCPlaster City. PGF- Painted Gorge Fault, some believe (Bykerk-Kauffman et al., 2016), is an active right lateral fault. Morgan and Morgan (2017b) believe PGF is a dip-slip fault, predominantly down to the north fault. PGWF- Painted Gorge Wash Fault is an active left-lateral fault (Morgan, and Morgan, 2006). VF - Vallicetos-Split Mountain-Fish Creek Basin. The town of Ocotillo is just off the slide, to the southeast of the center-edge of the map. 


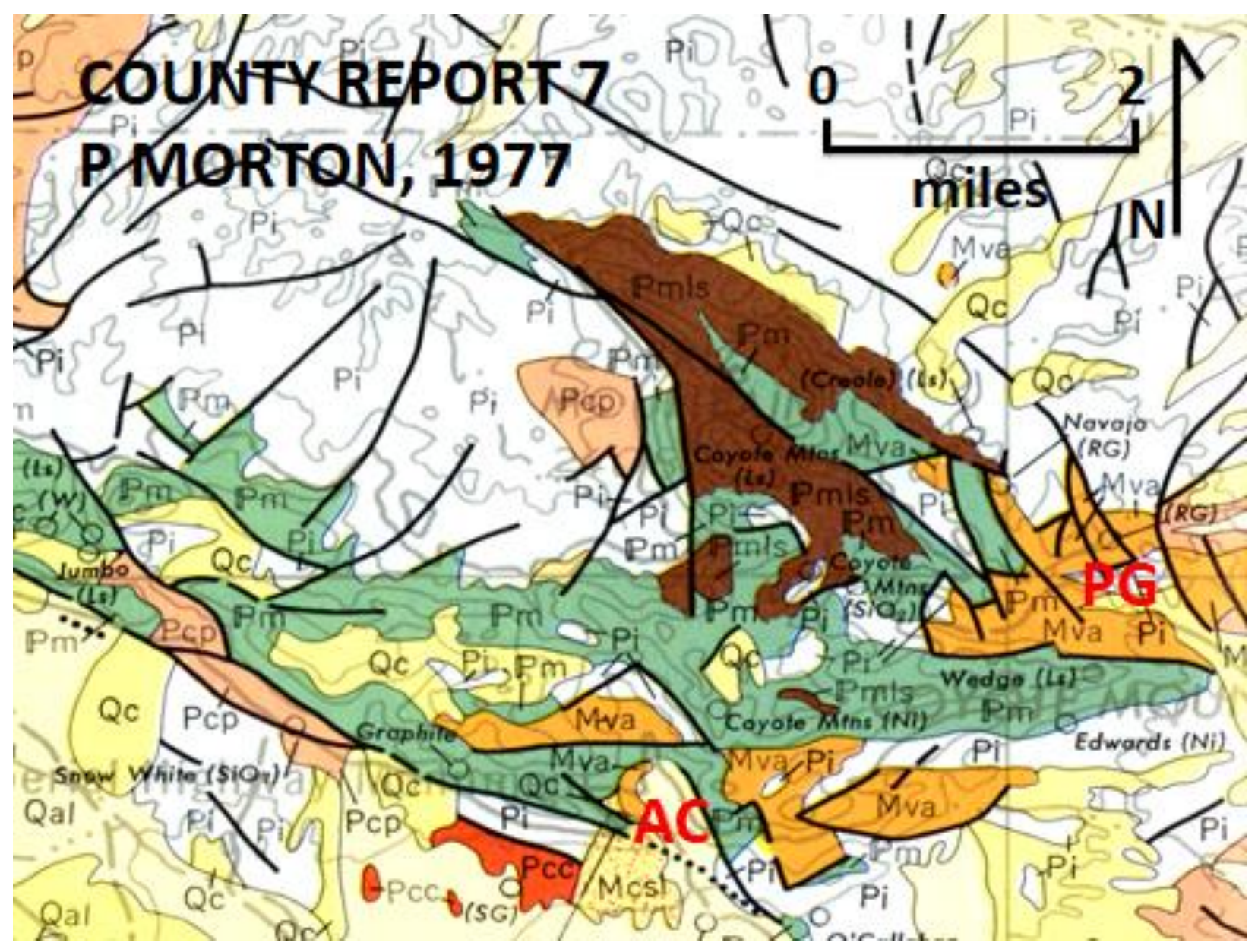

Slide 4. This is a portion of Morton's (1977) Geological map of Imperial County. Morton's map is a good summary of the geology found in and around the CMs. Morton used portions of Dibblee's (1954) and Christensen's (1957) maps for the geology around the CMs. Brown and green indicate the crystalline basement of the CMs. A simplified interpretation of the basement rocks consist of billow basalts and Paleozoic (?) (Dibblee, 1954; Miller and Dockum, 1983) limestones, sandstones, mudstones, cherts and conglomerates. Intruding, deforming and metamorphosing the section are igneous Jurassic rocks (Morgan and Morgan 2015). We have yet to find Cretaceous rocks in the CMs. The orange represents volcanics of the Alverson Canyon Formation (Ruisaard, 1979). The base of the Alverson is dated by 
Morgan et al. (2012) at 17.1 Ma using zircons. White represents the marine and fresh water units of the Imperial Group (Winker and Kidman, 1996), which interfingers with the volcanics of the Alverson Canyon Formation (Woodring, 1932; Morgan and Morgan, 2016). ACAlverson Canyon (Fossil Canyon). PG-Painted Gorge.

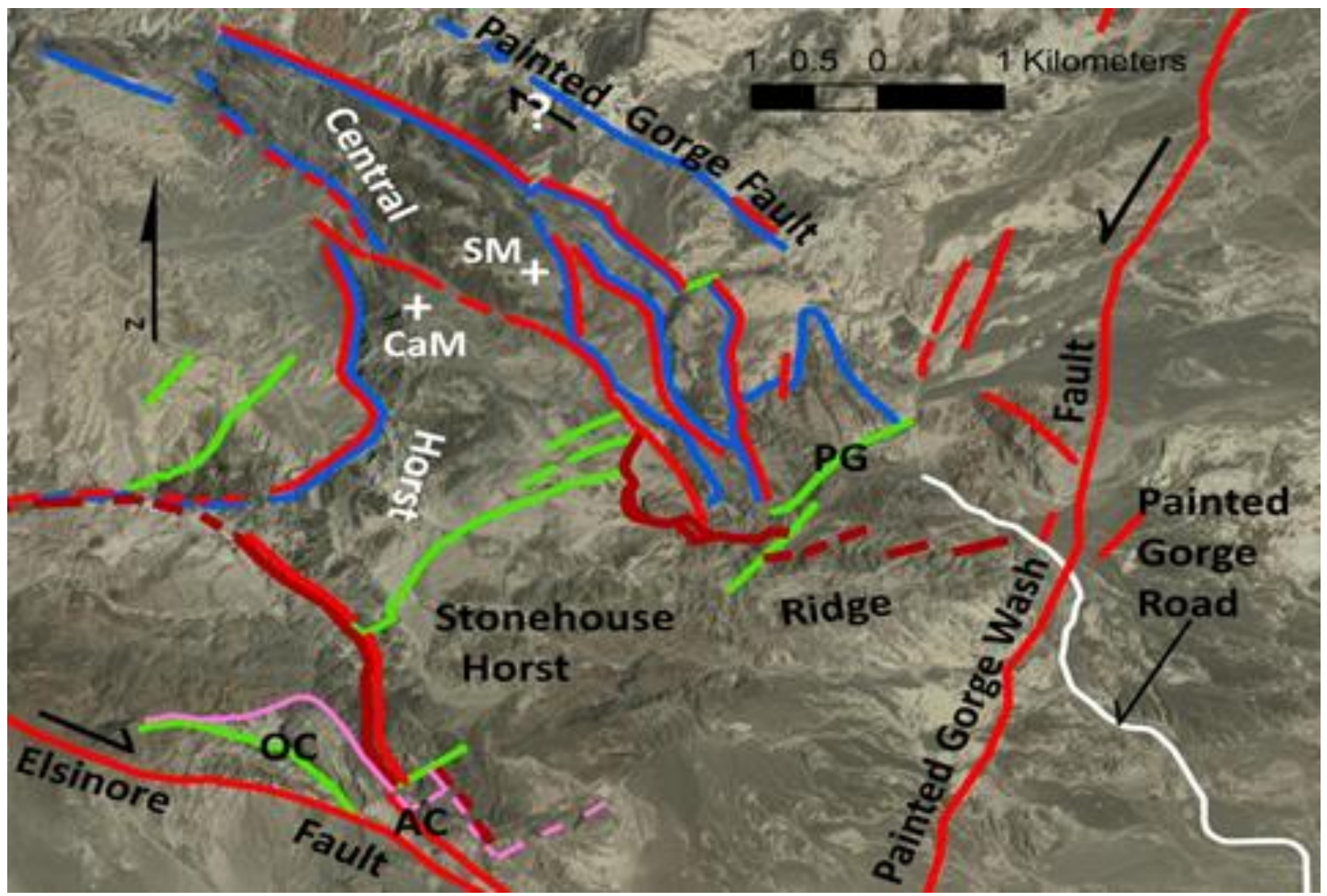

Slide 5. Map of the fish hook area of the CMs and some of the faults in the CMs (from Morgan and Morgan 2017a). AC - Alverson/Fossil Canyon. CaM - Carrizo Mountain. OC - Ocotillo Canyon. OCF Ocotillo Canyon Fault. NPF - Nickel Prospect Fault. PG - Painted Gorge. SM - Switchback Mountain. The active right-lateral Elsinore 
Fault forms the southwestern side of the $\mathrm{CMs}$ and the active left-lateral Painted Gorge Wash Fault forms a boundary on the east-southeastern side of the CMs. Pink lines are first extensional episode normal fault. The pink colored normal faults are associated with the Basin and Range extension in Sonora, Mexico. Note the pink Normal faults are $90^{\circ}$ clockwise from the northwest trending ranges of the Basin and Range Province in Sonora, Mexico (Slide 2). Brown lines are second extensional episode normal faults. Blue lines are third extensional episode normal faults. Red lines are $1 \mathrm{Ma}$ strike-slip faults (Steely et al., 2009). Green lines are other faults. The normal faults of the three episodes outline the half grabens, grabens and horsts associated with the three extensions. The white line is the Painted Gorge Road. Red faults that are close and parallel to older normal faults indicate reactivation of that older normal fault as $1 \mathrm{Ma}$ right-lateral faults. The horst for the first extensional episode is the topographic high, metamorphic block of Stonehouse Ridge. The normal faults of the second and third episodes are found on the east and west sides of the topographic high, metamorphic, fish-hock shaped, core of the CMs. We refer to this area as the Central Horst. Christensen (1957) named the Painted Gorge Fault and mapped it as a normal fault. Bykerk-Kauffman and others believe the Painted Gorge Fault to be an active right-lateral fault (Bykerk-Kauffman, et al., 2016). A recent fault scarp on the Pained Gorge Fault the shows very little strike-slip movement and more dipslip movement with the east side up (Morgan and Morgan, 2017b). Older offsets along the Painted Gorge Fault appear to be dip-slip with the east side up. We believe the Painted Gorge Fault is a normal fault that is a part of the third extensional episode found in the CMs (Morgan and Morgan, 2017a). We also are having trouble mapping the Painted 
Gorge Fault continuously to and crossing the Painted Gorge drainage (Morgan and Morgan, 2017b), as did Morton (1977) in Slide 4.

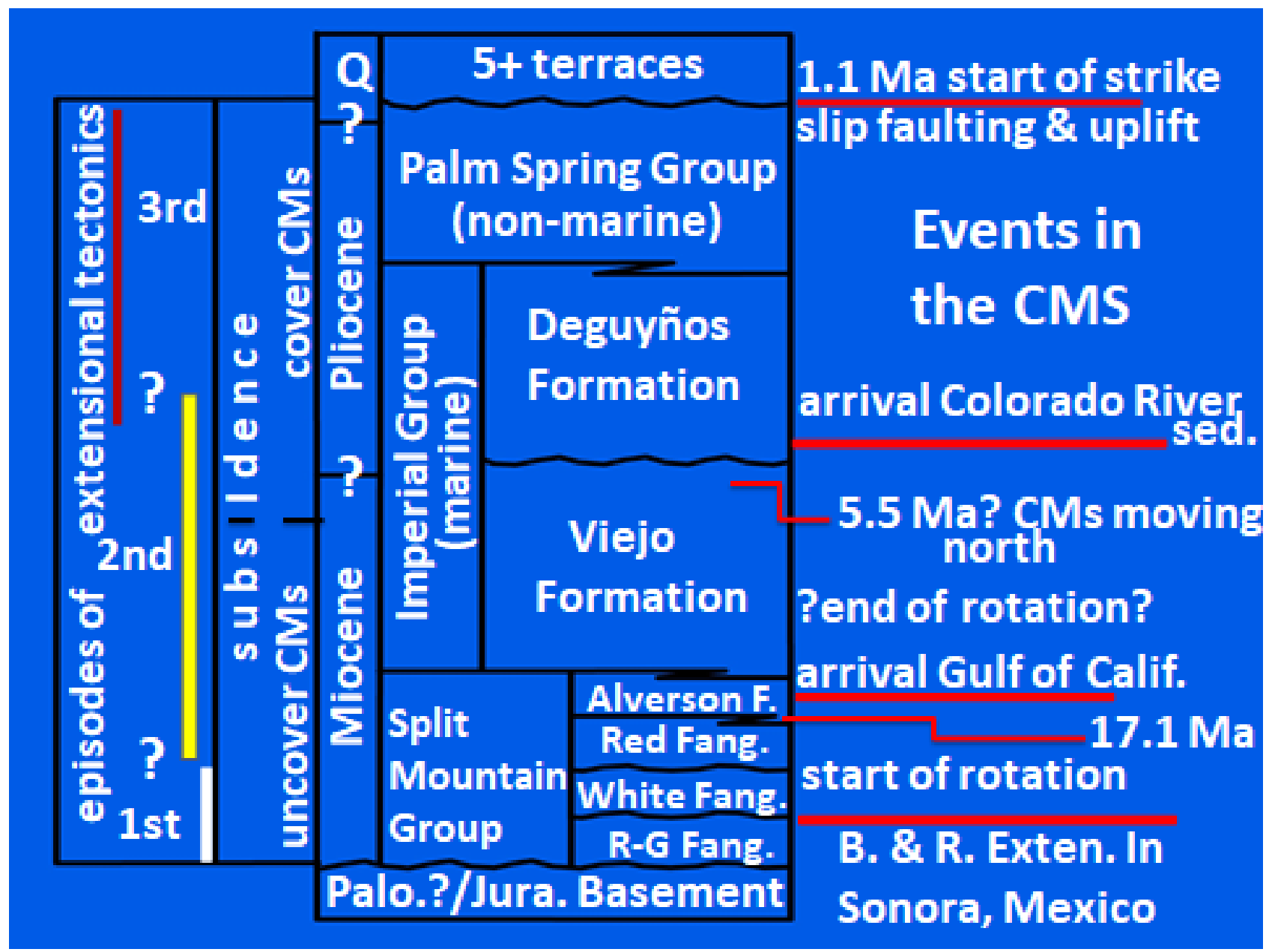

Slide 6. The three extensional episodes found in the $\mathrm{CMs}$ are shown in relation to the group and formational units, their relationship to each other and to events that took place in the CMs. The "?" mark between the second and third episodes is questing the timing of the end of the second and the start of the third episode. The "?" marks between the Cenozoic time units are questing the age boundaries in the sedimentary units. B. \& R. - Basin and Range. F - Formation. Fang - Fanglomerate. 
R.-G. - Red-Green Fanglomerate. $17.1 \mathrm{Ma}-\mathrm{U} / \mathrm{Pb}$ zircon age date by Morgan, et al., 2012.

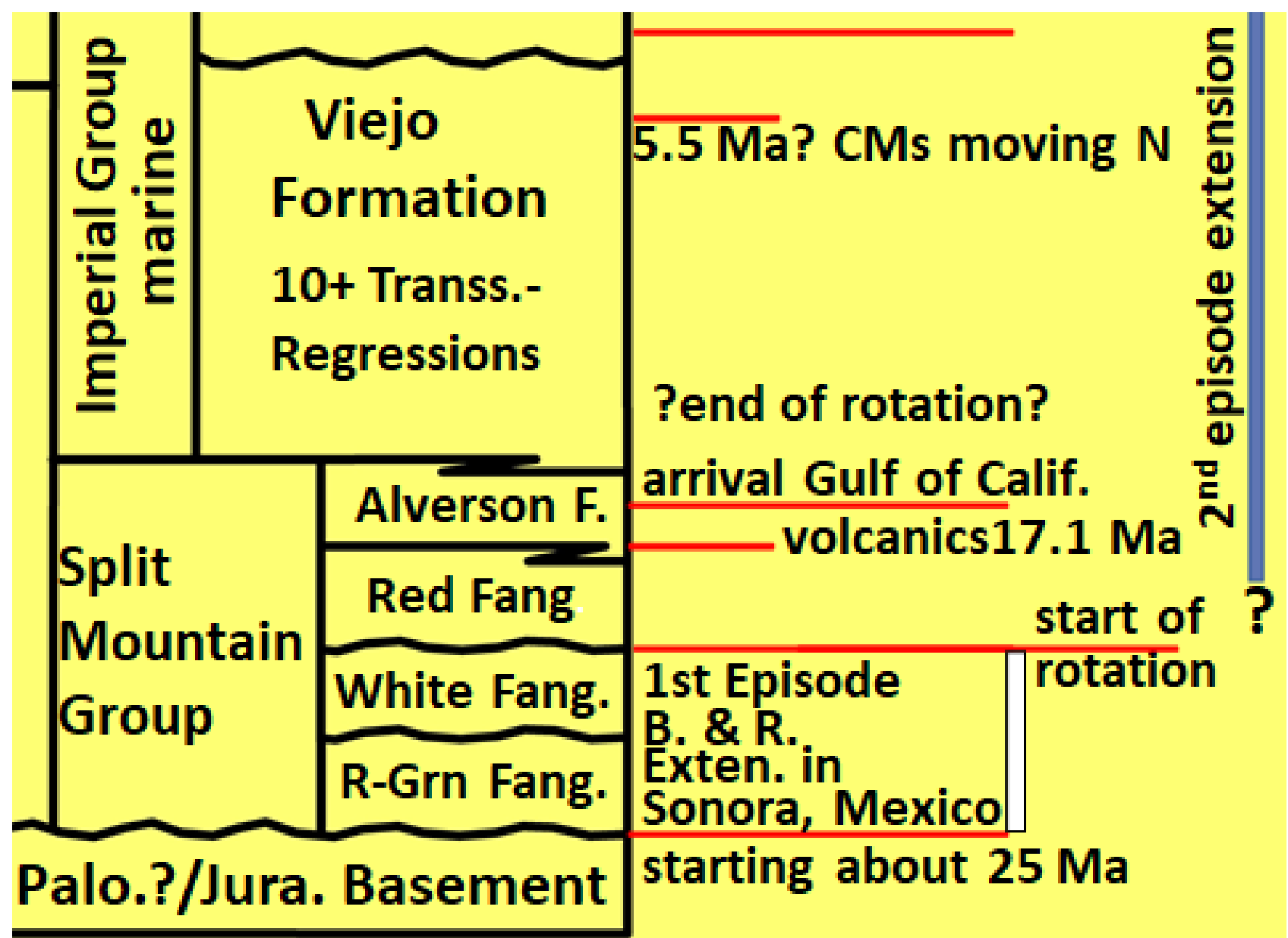

Slide 7. About $25 \mathrm{Ma}$ Basin and Range extension started in Sonora, Mexico (Nourse et al., 1994; McDowell, et al., 1997). During this extension the Red-Green Fanglomerate and the White Fanglomerate of the SMG were syn-extensionally deposited in the CMs. It should be noted that the clockwise rotation started about the time the first episode of extensional tectonics ended in the CMs. The Red Fanglomerate and the volcanics of the Alverson Canyon Formation of the SMG are syn-extensionally related to the second episode of extensional found in the CMs. The Red Fanglomerate interfingers with 
the Alverson Canyon Formation (Ruisaard, 1979) with the Viejo Formation also interfingering with the Alverson (Woodring, 1931; Morgan and Morgan 2016). This second episode appears to be related to continuing Basin and Range extension and the arrival of the Gulf of California (Viejo Formation). The continuing rotation of the $\mathrm{CMs}$ is recorded with two paleomagnetic (Mace, 1981) locations that are in the volcanics of the Alverson. One location shows $34^{\circ}$ and the other $70^{\circ}$ of clockwise rotation. These two locations are in volcanics that are deposited on stable(?) Stonehouse Ridge Horst. Mace has other paleomagnetic locations with unreliable data. The unreliable data is found in the more tectonically active (unstable) grabens. Rotation ends sometime after the start of the second episode of extension. 


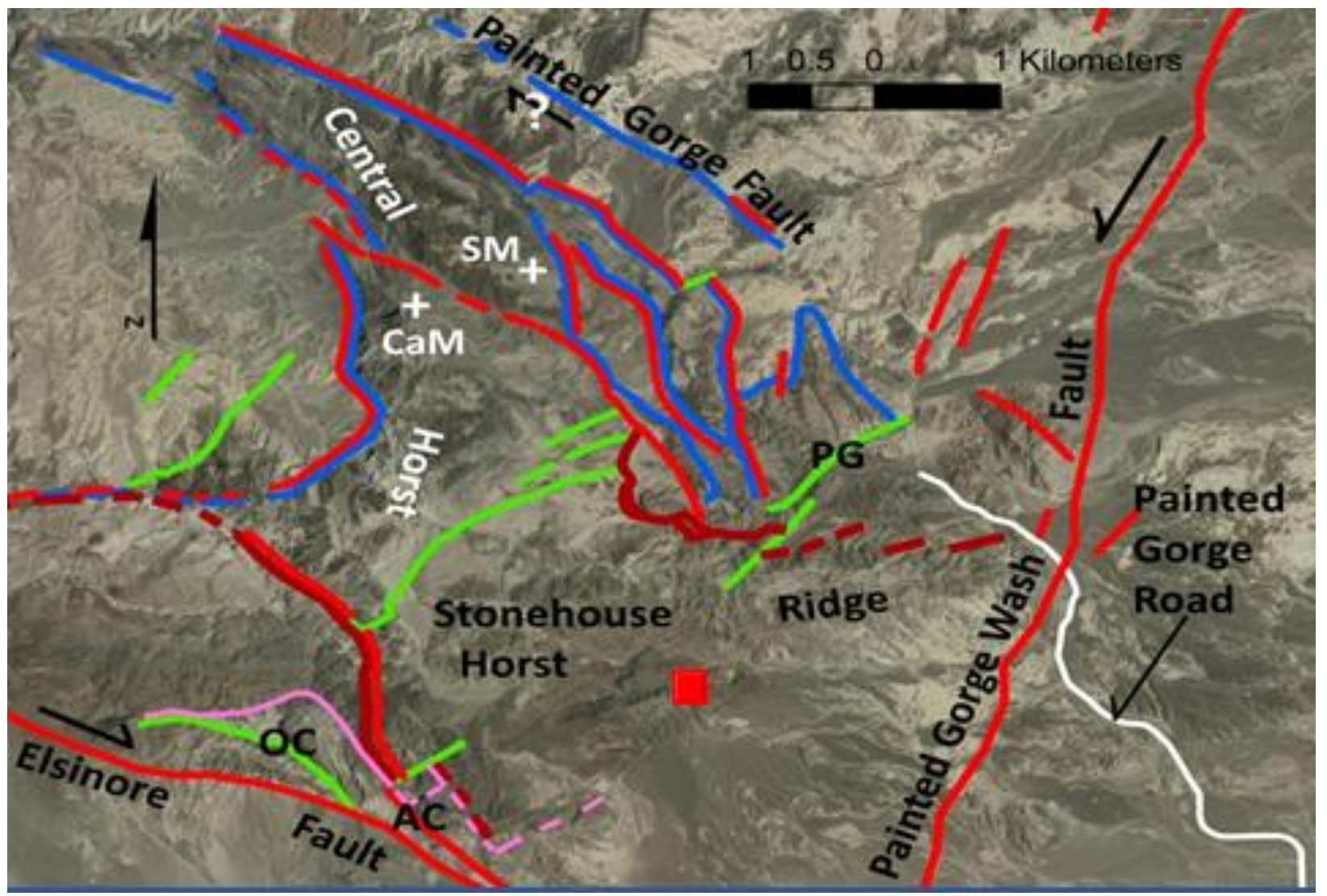

Slide 8. Red square shows the location of Mace's two paleomagnetic locations on Stonehouse Ridge Horst. Note location of the pink lines that delineate the faults associated with the first episode of extensional tectonics in the CMs. 


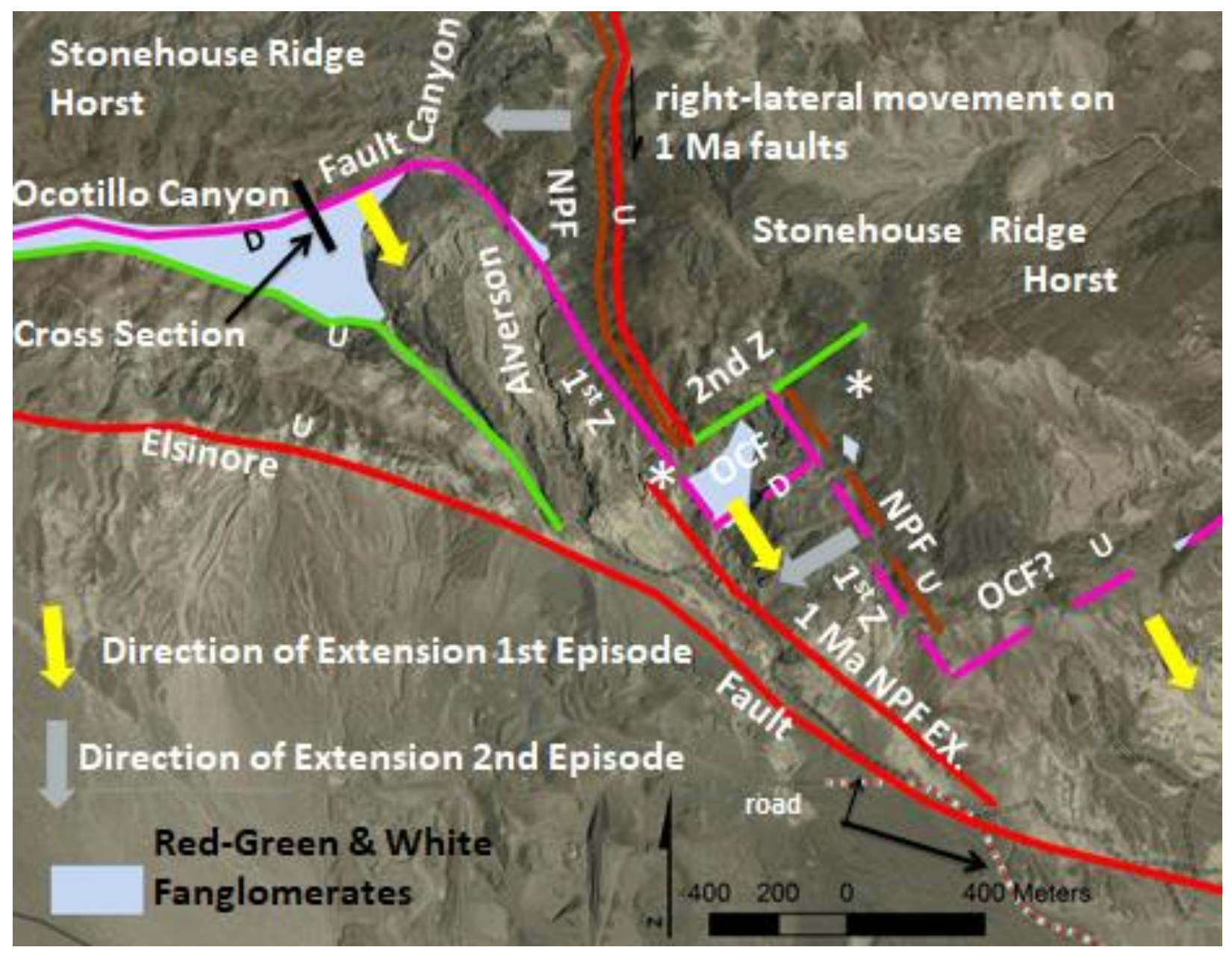

Slide 9. Map of Ocotillo Canyon (from Morgan and Morgan 2017a), Alverson Canyon (Fossil Canyon) area. Pink lines are the Ocotillo Canyon Fault (OCF), a normal fault of the first episode extensional tectonics (Basin and Range extension that took place in Sonora). The Ocotillo Canyon Fault strike east-northeast and is cut in to three parts by two zones of accommodation (1st Z) striking north-northwest. The three branches of the Ocotillo Canyon Fault may have been at one time continues. The $\mathbf{T}$ represents areas where thrust faults are mapped. The $\mathbf{U}$ designates the up side of a fault. The extension of the first episode was to the south-southeast. The southern two parts of the Ocotillo Canyon Fault and half grabens of the first episode are buried by the Red Fanglomerate and volcanics of the Alverson Canyon Formation. 
The two parts of the Ocotillo Canyon Fault and half grabens are inferred to be there by the presence of the Red-Green and White Fanglomerates on the southern sides of the buttress unconformities formed on the Stonehouse Ridge Horst. This is the same geological relationship that is present on the northern side of Ocotillo Canyon where the normal Ocotillo Canyon Fault cuts the Red-Green and White Fanglomerates. The brown lines are traces of the Nickel Prospect Fault (NPF), a curved, normal fault that is a part of the western, second extensional episode in the CMs. Extension of the western second episode was to the southwest. The east-northeast green fault is a western, second episode zone of accommodation between the two traces of the Nickel Prospect Fault and the two half grabens of the second episode. North of the second zone of accommodation, the Nickel Prospect Fault cuts and offset the first episode's half graben and a western part of the Stonehouse Ridge Horst. After extensional tectonics ended in the CMs and strike-slip faulting started (Steely et al., 2009), the Nickel Prospect Fault was reactivated as a $1 \mathrm{Ma}$ right-lateral fault and further separated the northern, Ocotillo Canyon Fault and its half graben from the southern part of Ocotillo Canyon Fault and its half grabens by an estimated $400 \mathrm{~m}$ right laterally. South of the second zone of accommodation, the southern part Nickel Prospect Fault that is parallel to a first zone of accommodation, offsets marker beds in the postextensional sediments (Viejo Formation) of the first episode vertically from the same units on Stonehouse Ridge Horst by an estimated $220 \mathrm{~m}$ (between the two asterisks of this slide and slide 1). The right-lateral fault (red line) labeled 1Ma NPF EX., south of the second zone of accommodation, is a right-lateral extension of the northern Nickel Prospect Fault. This extension of the $1 \mathrm{Ma}$ right-lateral fault cuts the 
sediments in the second southern half graben. The east-west to southsoutheast younger green fault just east of the Elsinore Fault truncated and removed a southern part of the first episode half graben. The Elsinore Fault also cuts the half grabens and truncated many of the faults of the first and second episodes of extension.

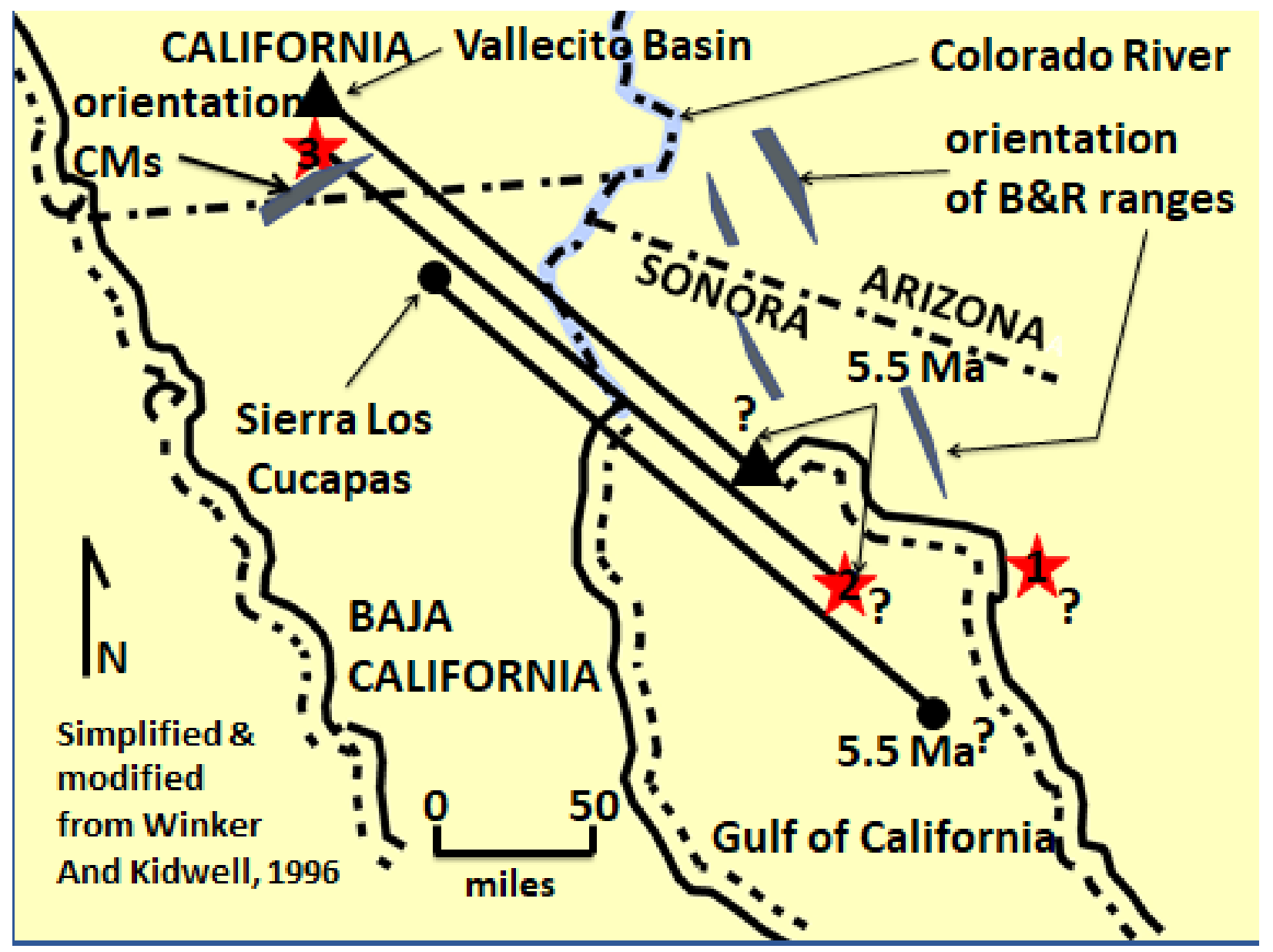

Slide 10. Simplified and modified map from Winker and Kidwell (1996) showing possible locations of the Coyote Mountains (CMs), and orientation of the ranges of the Basin and Range Province. 1 and 2 numbered red stars are possible locations for the CMs in Sonora. Note 
orientation of the CMs in California: $90^{\circ}$ clockwise rotation from the orientation of the ranges of the Basin and Range Province in Sonora.

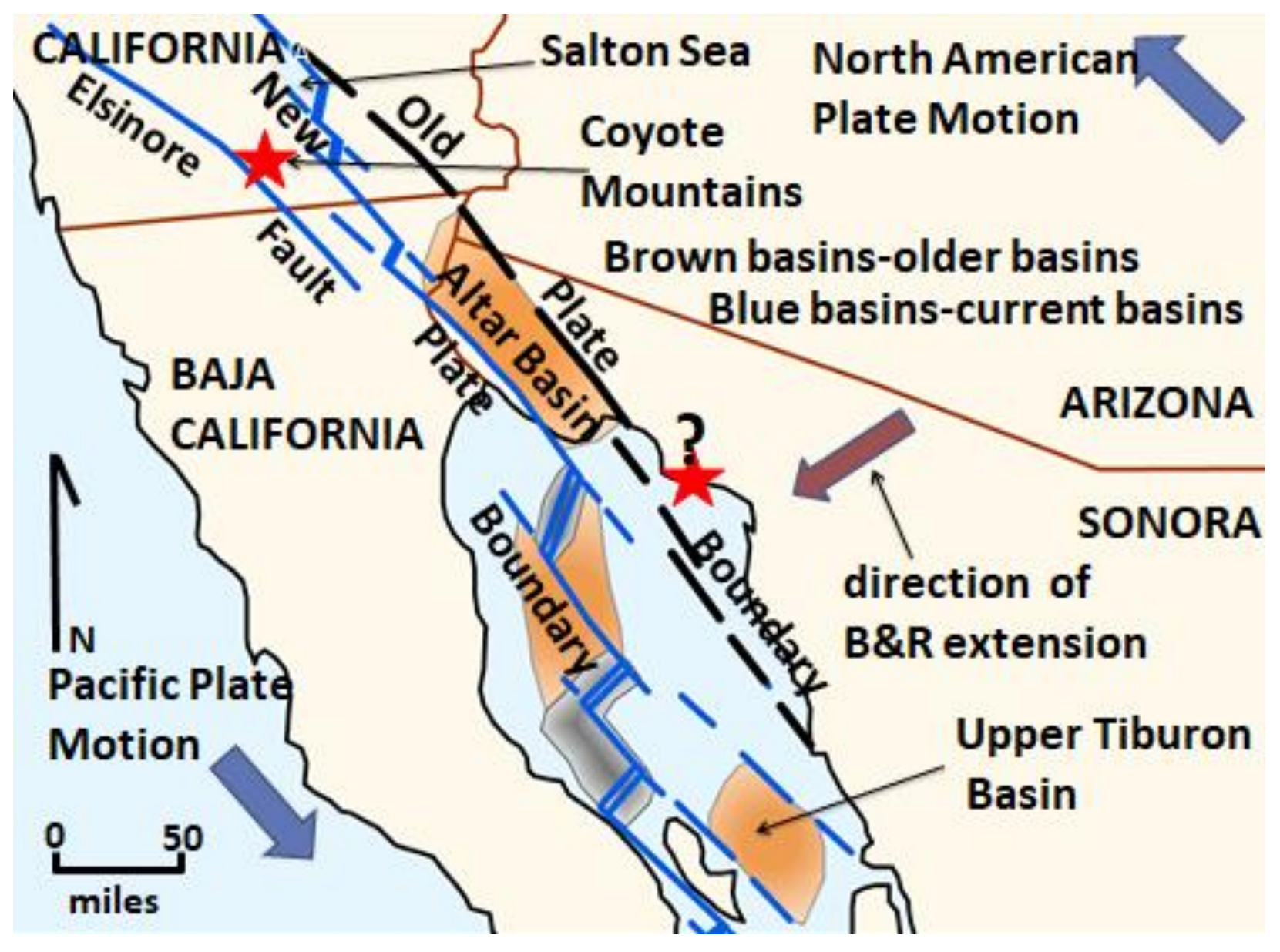

Slide 11. Simplified map of the present day northern Gulf of Californian, Salton Trough, California, Baja California, Arizona and Sonora. Data in part from Helenes, et al., 2009, Martín-Barajas, et al., 2013; and Aragón-Arreola, and Martín-Barajas, 2007. Brown areas are older basins associated with the Old Plate Boundary. Blue and gray areas are basins associated with the New Plate Boundary. Red star with question mark is a possible location of the CMs in Sonora. 


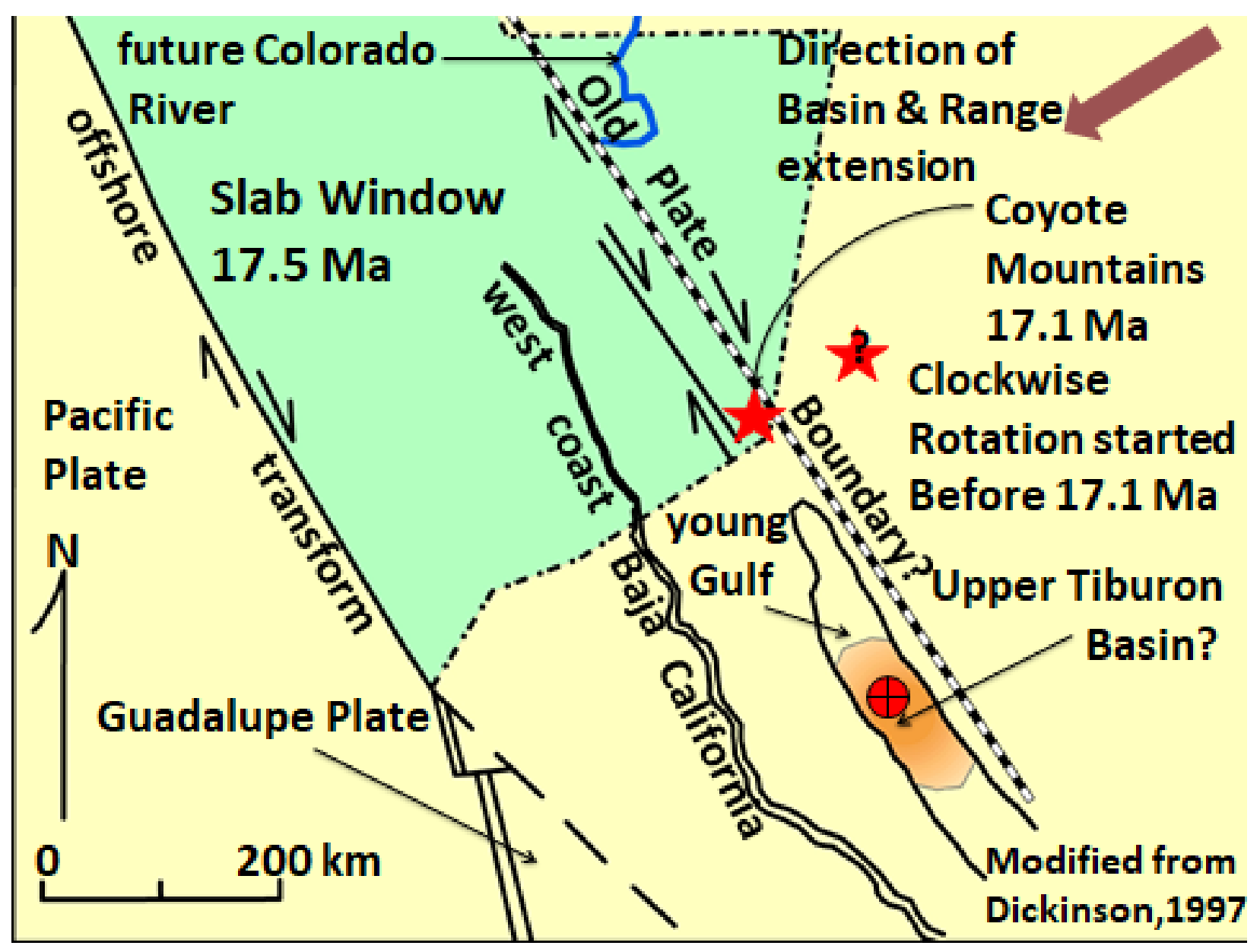

Slide 10. Map of Northern Gulf of California about 17.5 Ma. Modified from Dickinson, 1997. Red stare with question mark and labeled $\mathbf{1}$ is a possible location for the CMs. Basin and Range extension moves the CMs to the west-southwest over what will become or has already become the Old Plate Boundary. When the CMs cross(?) the boundary, right-lateral faulting (with possible transitional component) starts to rotate the CMs clockwise. Rightlateral transtensional faulting has already started on the offshore transform fault. The rotation continues through the deposition of the Volcanics of the Alverson Canyon Formation and ends(?) sometime during the second episode of extension in the CMs. The CMs are left with about $90^{\circ}$ of clockwise rotation. The young Gulf of California arrives in the CMs (Sonora) around 17.1Ma (late-early to early-middle Miocene) and deposits sediment near sea-level (during second episode of extension in the CMs). At the same time in the 
Upper Tiburon Basin, late-early to early-middle Miocene ( 17.1 Ma) sediments are deposited in deeper water: a basin that is today 5,000m deep (Helenes et al., 2009). McDowell et al. (1997) observed that the extensional tectonics of the Basin and Range in Sonora continued and was "coeval with initial evolution" (arrival) of the Gulf of California.

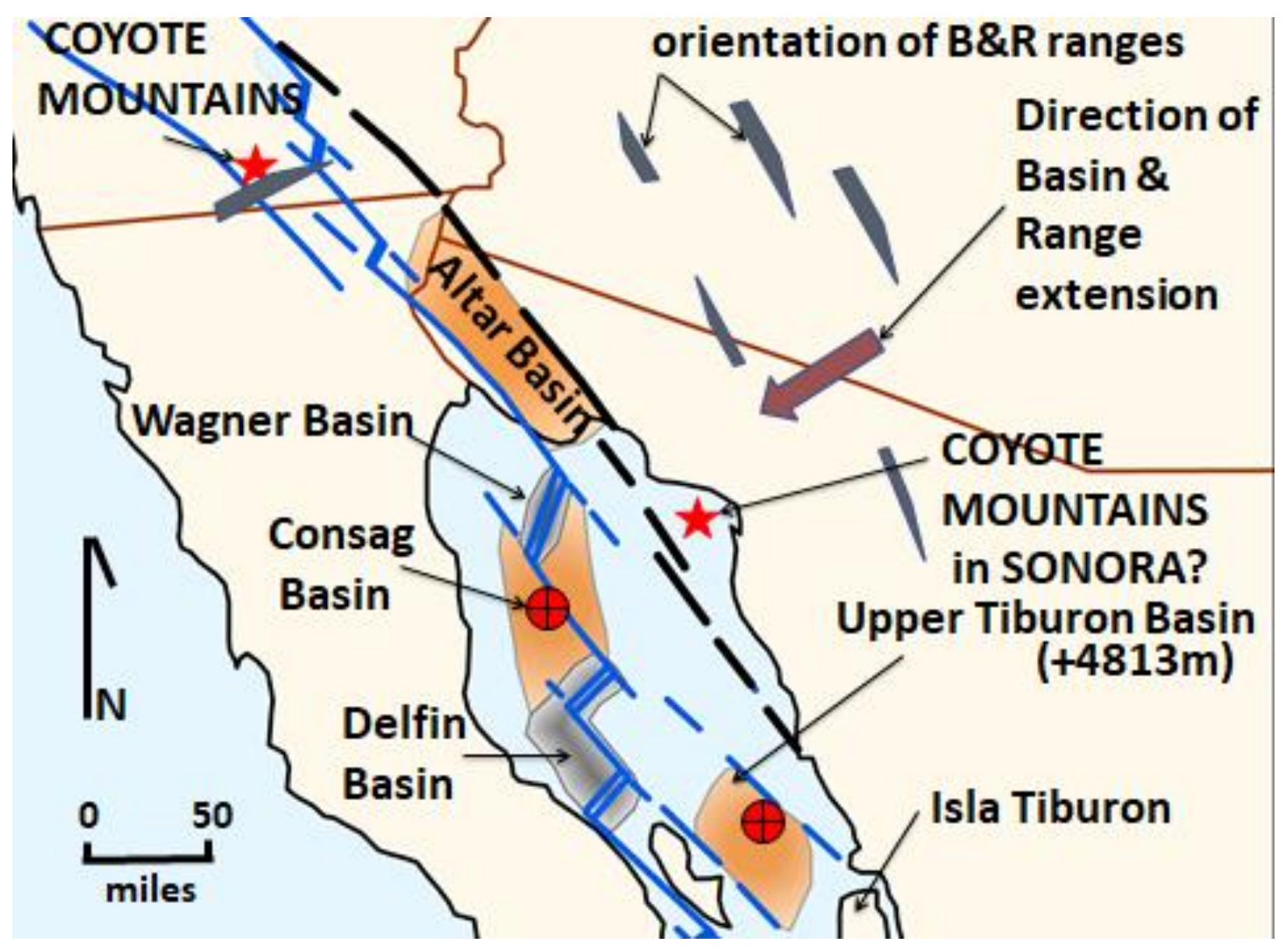

Slide 11. Map of the present day northern Gulf of California. Red bullseyes represent Petróleos Mexicanos (PEMEX) drill holes (Helenes et al., 2009). With extension and subsidence of a warm (volcanism) thin crust one would expect to fine pull-apart basins in the then young Gulf of California. Brown areas (Upper Tiburon, Consag and Altar Basins) are those old basins associated with 
extension and subsidence of a warm (volcanism) thin crust. These basins are also associated with the development of the then young Gulf of California and the Old Plate Boundary. Helenes et al. (2009) suggest that the proto (older) Gulf of California used basins produced during the Miocene extension of the Basin and Range in Sonora.

The CMs may have stated somewhere in Sonora, but they end up north of the international border next to the Elsinore Fault. There are two major geological boundaries that the CMs have to cross: the Old Plate Boundary and the New Plate Boundary. Basin and Range extension moved the CMs to the west. If the extension doesn't move the CMs far enough to the west, west side of the Old Plate Boundary, then the CMs would have say in Sonora. The rotation of the CMs and arrival of the Gulf of California are indications that the CMs were moved to the west side of the Old Plate Boundary.

McDowell et al. (1997) observation that the extensional tectonics of the Basin and Range in Sonora may have continued and been "coeval with initial evolution" of the right-lateral transtension tectonics that produced the Gulf of California. The second episode of extension tectonics in the CMs coincides with McDowell et al. observations (Morgan and Morgan, 2017a). This second episode of extension has to move the CMs west of the New Plate Boundary, before the new boundary is established. If not then the CMs would have stay in Sonora.

The exact path out of Sonora is unknown but the CMs make it west of both plate boundaries and ended up north of the International border, in the Salton Trough and along the Elsinore Fault.

Thanks to: John Prall, Bill Elliott, Mike Hart, Ann Bykerk-Kauffman, Eric Frost, Stephen Schellenberg, Monte Marshall, Thomas Zmudka, Gordon 
Gastil, Gary Axen, Larry Busch, Charles Winker, Jerry Treiman, Jim Senn and the BLM, El Centro Office for a mapping permit.

\section{References:}

Aragón-Arreola, M., and Martín-Barajas, A., 2007, Westward migration of extension in the northern Gulf of California, Mexico: Geology, v. 35, p. 571-574, doi: 10.1130 /G23360A.1.

Bennett, S. E. K., Oskin, M. E, Dorsey, R. J., Iriondo, A., and Kunk, M. J., 2015, Stratigraphy and structural development of the southwest Isla Tiburón marine basin: Implications for latest Miocene tectonic opening and flooding of the northern Gulf of California, Geoshere, V, 11, no. 4, p. 977-1007.

Bykerk-Kauffman, A., Janecke, S. U., Ewing, C. S., Brenneman, M. J., Caldwell, G. R. and Gentry, A. C., 2016, A complex fault network in an active zone of distributed right-lateral shear, Coyote Mountains, southern California, GSA Annual Meeting, abstract.

Christensen, A. D., 1957, Part of the geology of the Coyote Mountains area, Imperial County, California: Unpublished M.S. thesis, University of California at Los Angeles, 188p.

Dibblee, T. W., 1954, Geology of the Imperial Valley region, California, in Jahns, R. H., ed., Geology of southern California: California Division Mines Bulletin, v. 170, p. 21-28.

Dickinson, W.R., 1997, Tectonic implications of Cenozoic volcanism in coastal California: Geological Society of America Bulletin, v. 106, no. 8, p. 936-954.

Helenes, J., Carreno A.L., and Carrillo R.M., (2009), Middle to late Miocene chronostratigraphy and development of the northern Gulf of California, Mar. Micropaleontol., 72, 10 
Mace, N.W., 1981, A paleomagnetic study of the Miocene Alverson Volcanics of the Coyote Mountains, western Salton Trough, California: a Master's Thesis at San Diego State University, 142p.

Martín-Barajas, A., M. González-Escobar, J. M. Fletcher, M. Pacheco, M. Oskin, and R. Dorsey (2013), Thick deltaic sedimentation and detachment faulting delay the onset of continental rupture in the Northern Gulf of California: Analysis of seismic reflection profiles, Tectonics, 32, 1294-1311, doi:10.1002/tect.20063.

McDowell, F.W., Roldán-Quintana, J., and Amaya-Martínez, R., 1997, Interrelationship of sedimentary and volcanic deposits associated with Tertiary extension in Sonora, Mexico: Geological Society of America Bulletin, v. 109, p. 1349-1360, doi: 10.1130/00167606(1997)109<1349: IOSAVD>2.3.COMiller, R, H., and Dockum, M. S., 1983, Ordovician conodonts from metamorphosed carbonates of the Salton Trough, California: Geology, v. 11, p. 410-412.

Morgan, G. J., and Morgan, J. R., 2006, The Painted Gorge Wash Fault: recent left-lateral faulting, east side Coyote Mountains, Imperial County, California: Bloom, D. M., ed. Geology and history of southeastern San Diego County, California, San Diego Association of Geologists, p.189-204.

Morgan, J. R., Morgan, G. J. and Pecha, M., 2012, U/Pb dating of tuffs from the Alverson Volcanics in the Fossil Canyon and Painted Gorge areas of the Coyote Mountains, western Salton Trough, California, GSA, Abstract and Programs, Vol. 44, No. 3, p. 22.

Morgan, G. J., and Morgan, J. R., 2015, Overview of the Geology of the southern Coyote Mountains, Salton Trough, Imperial County, southern California. In Wagner, R., ed., Geology of the Coyote Mountains, southern California: San Diego Association of Geologists, p.77-87. 
Morgan, G. J. and Morgan, J.R., 2016, Viejo Formation: a new formation for the Imperial Group sediments in the southern Coyote Mountains, Salton Trough, southern California, GSA Cordilleran Section, Abstract Paper No. 28-10.

Morgan, G. J. and Morgan, J.R., 2017a, Miocene(?) to late Pleistocene Extensional Tectonics in the Coyote Mountains, western Salton Trough, southern California: Ecsy Does It, Revisiting the eastern California Shear Zone, 2017 Desert Symposium Field Guide and Proceedings; Robert E Reynolds, editor; California State University Desert Studies Consortium, p, 194-206.

Morgan, G. J. and Morgan, J.R., 2017b, The Mud Hills and Yuha Members of the Deguynos Formation in the northern Coyote Mountains, western Salton Trough, southern California and problems with a right-lateral offset of a hornblende andesite plug by the Painted Gorge Fault: Ecsy Does It, Revisiting the eastern California Shear Zone, 2017 Desert Symposium Field Guide and Proceedings; Robert E Reynolds, editor; California State University Desert Studies Consortium, p, 207-215.

Nourse, J. A., Anderson. T. A., and Silver, L. T., 1994, Tertiary metamorphic core complexes in Sonora, northwest Mexico: Tectonics, v.13, p. 1161-1182.

Ruisaard, C. I., 1979, Stratigraphy of the Miocene Alverson Formation, Imperial County, California: Master Thesis, San Diego State University, $125 p$.

Steely, A. N., Janecke, S. U., Dorsey, R. J., and Axen, G. J., 2009, Early Pleistocene initiation of the San Felipe fault zone, SW Salton Trough, during reorganization of the San Andreas Fault System: Geological Society of America Bulletin, v. 121, P. 663-687, doi. 10.1130/B26239.1. 
Winker, C. D., and Kidwell, S. M., 1996, Stratigraphy of a marine rift basin: Neogene of the western Salton Trough, California, in Abbott, P. L., and Cooper, J. D., eds., Field Conference Guidebook and Volume for the Annual Convention: San Diego, California, American Association of Petroleum Geologists, Pacific Section, p. 295-336.

Woodring, W. P., 1931, Distribution and age of the Tertiary Deposits of the Colorado Desert: Carnegie Institution of Washington Publication 148, p. 1-25. 